\title{
Hypoglycaemia Complicating Haemolytic Disease of the Newborn
}

\author{
H. V. PRICE \\ From the University Department of Child Health and the Queen Mother's Hospital, Glasgow
}

\begin{abstract}
The association of hypoglycaemia with haemolytic disease of the newborn has been previously recorded (Gerrard, 1952; Hazeltine, 1967; MacRae and Palavradji, 1965; Lucey, Randall, and Murray 1967), but doubt has also been expressed whether there is in fact an increased incidence of hypoglycaemia in this condition (Driscoll, 1966). In support of this association a further 6 cases are reported. Before the introduction of Dextrostix testing (Campbell et al., 1967), it was easy to overlook hypoglycaemia in an infant already suffering from severe haemolytic disease of the newborn and in whom there might also be metabolic acidosis, hypocalcaemia, hyperkalaemia, or hypothermia. All 6 cases were detected by Dextrostix testing which is carried out as a routine on every infant immediately upon admission to the special-care department. Table I shows the relevant clinical data and Table II the haematological, serological, and biochemical data.
\end{abstract}

\section{Materials and Methods}

During an 18-month period 86 infants were admitted to the paediatric department of the Queen Mother's Hospital with haemolytic disease of the newborn, and 54 of them required exchange transfusion. Of the 86 infants, 6 developed significant hypoglycaemia characterized by a true blood glucose level below $20 \mathrm{mg}$./100 ml., and all had symptoms which were relieved by intravenous dextrose. 2 of the 6 affected infants had received one or more intrauterine transfusions, and 2 died of intracranial haemorrhage.

All exchange transfusions were carried out with blood bank stocks less than 4 days old. One bottle of bank blood contains approximately $420 \mathrm{ml}$. donor blood taken into $120 \mathrm{ml}$. acid citrate/dextrose solution containing $3 \mathrm{~g}$. dextrose. The volume of exchange transfusion was usually $160 \mathrm{ml} . / \mathrm{kg}$. body weight, and was timed to take at least two hours. $1 \mathrm{ml} .10 \%$ calcium gluconate and $1 \mathrm{ml} .8 \cdot 4 \%$ sodium bicarbonate were given with each $100 \mathrm{ml}$. blood transfused, bicarbonate being omitted in repeat transfusions. Hypoglycaemia was treated intravenously with an initial

Received July 18, 1968. dose of $\mathbf{5 0} \%$ dextrose $2 \mathrm{ml} . / \mathrm{kg}$. body weight, followed by $10 \%$ r'extrose $60 \mathrm{ml} . / \mathrm{kg}$. per day. The Dextrostix tests were carried out by both medical and nursing staff. True blood glucose was measured by the method of Marks (1959).

Case 1. This infant had severe icterus gravis neonatorum. Amniocentesis at 32 weeks' gestation produced fluid in zone 3 by Liley's method, and was followed by two intrauterine blood transfusions. Mild respiratory distress syndrome developed during the first exchange transfusion carried out at 1 hour. Heel blood tests at 10 hours were: $\mathrm{Hb} 13 \mathrm{~g} . / 100 \mathrm{ml}$., serum bilirubin $13 \mathrm{mg} . / 100 \mathrm{ml}$., pH 7.27, Pco. $53 \mathrm{~mm}$. Hg, base deficit $3.5 \mathrm{mEq} / \mathrm{l}$. Recurrent limb twitching was noted 15 hours after birth when Dextrostix failed to record and blood glucose was under $5 \mathrm{mg} . / 100 \mathrm{ml}$. Intravenous dextrose relieved the symptoms and was continued for $\mathbf{7 2}$ hours. Dextrostix thereafter recorded $40-65 \mathrm{mg} . / 100 \mathrm{ml}$. The infant remained in relatively good condition apart from hyperbilirubinaemia, for which a further three exchange transfusions were required. When 2 years old her development was normal.

Case 2. This severely affected infant received intrauterine blood transfusions 21 and 10 days before delivery, $80 \%$ of circulating red cells being of donor type at birth. Paracentesis abdominis produced $7 \mathrm{ml}$. fluid containing bilirubin $7 \mathrm{mg}$. $/ 100 \mathrm{ml}$. After correction of metabolic acidosis $\left(p \mathrm{H} \mathrm{7} \cdot 17, \mathrm{PcO}_{2} 56 \mathrm{~mm}\right.$. Hg, base deficit $6 \mathrm{mEq} / \mathrm{l}$.), $200 \mathrm{ml}$. blood was slowly exchanged-beginning half an hour after birth. The infant showed slightly tremulous movements, and 4 hours after birth Dextrostix failed to register; true blood glucose was under $5 \mathrm{mg} . / 100 \mathrm{ml}$. $6 \mathrm{ml} .50 \%$ dextrose was infused before the next exchange transfusion and thereafter $5 \mathrm{ml} .20 \%$ fructose was given hourly via the umbilical catheter. Dextrostix ther after recorded $40 \mathrm{mg} . / 100 \mathrm{ml}$. or higher. Blood sugar results 20 and 47 hours after birth were-reducing substances 69 and $84 \mathrm{mg} . / 100 \mathrm{ml}$., true glucose 10 and $23 \mathrm{mg} . / 100 \mathrm{ml}$., respectively. Two further exchange transfusions were required for hyperbilirubinaemia 31 and 54 hours after birth. An apnoeic bout 47 hours after birth was apparently relieved by $10 \mathrm{ml}$. intravenous $50 \%$ dextrose, but recovery occurred spon- 
TABLE I

Summary of Clinical Data

\begin{tabular}{|c|c|c|c|c|c|c|c|c|c|c|c|}
\hline \multirow{2}{*}{$\begin{array}{l}\text { Case } \\
\text { No. }\end{array}$} & \multirow{2}{*}{ Sex } & \multirow{2}{*}{$\begin{array}{l}\text { Gestation } \\
\text { (wk.) }\end{array}$} & \multirow{2}{*}{$\begin{array}{l}\text { Birth- } \\
\text { weight } \\
\text { (g.) }\end{array}$} & \multirow{2}{*}{ Pregnancy } & \multirow{2}{*}{ Delivery } & \multirow{2}{*}{$\begin{array}{c}\text { Apgar } \\
\text { Score } \\
(2 \text { min. })\end{array}$} & \multicolumn{4}{|c|}{ Clinical Signs at Birth } & \multirow{2}{*}{ Result } \\
\hline & & & & & & & Oedema & Liver & Spleen & Purpura & \\
\hline 1 & $\mathbf{F}$ & 35 & 1770 & $\begin{array}{l}\text { Gravida } 6, \\
\text { para } 2 ; \\
2 \text { intra- } \\
\text { uterine } \\
\text { transfusions }\end{array}$ & $\begin{array}{c}\text { Caesarean } \\
\text { section }\end{array}$ & 3 & ++ & $3 \mathrm{~cm}$. & $2 \mathrm{~cm}$ & + & Normal \\
\hline 2 & $\mathbf{M}$ & 35 & 2470 & $\begin{array}{l}\text { Para } 2 ; 2 \text { intra- } \\
\text { uterine } \\
\text { transfusions }\end{array}$ & $\begin{array}{c}\text { Caesarean } \\
\text { section }\end{array}$ & 2 & +++ & $3 \mathrm{~cm}$. & $3 \mathrm{~cm}$. & + & Normal \\
\hline 3 & $\mathrm{~F}$ & 36 & $1340^{\star}$ & $\begin{array}{l}\text { Para } 5 ; \\
\text { severe } \\
\text { toxaemia }\end{array}$ & $\begin{array}{c}\text { Caesarean } \\
\text { section }\end{array}$ & 6 & 0 & $1 \mathrm{~cm}$. & - & - & Satisfactory \\
\hline 4 & $\mathbf{M}$ & 37 & 2380 & $\begin{array}{c}\text { Para } 2 ; \text { mild } \\
\text { toxaemia }\end{array}$ & $\begin{array}{l}\text { Vaginal, with } \\
\text { forceps }\end{array}$ & 10 & + & $2 \mathrm{~cm}$. & $1 \mathrm{~cm}$ & 一 & Normal \\
\hline 5 & $\mathbf{F}$ & 40 & $2340^{\star}$ & Para 2 & Vaginal & 4 & 0 & $1 \mathrm{~cm}$. & - & - & $\left\{\begin{array}{l}\text { Died, intra- } \\
\text { cranial }\end{array}\right.$ \\
\hline \multirow[t]{2}{*}{6} & $\mathbf{F}$ & 38 & 2680 & Para 2 & Vaginal & 4 & +++ & $4 \mathrm{~cm}$. & $3 \mathrm{~cm}$ & + & $\begin{array}{l}\text { haemor- } \\
\text { rhage }\end{array}$ \\
\hline & & i & & & & & 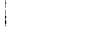 & & & & \\
\hline
\end{tabular}

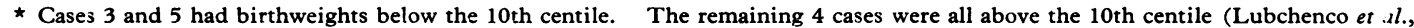
1963).

TABLE II

Haematological, Serological, and Biochemical Data

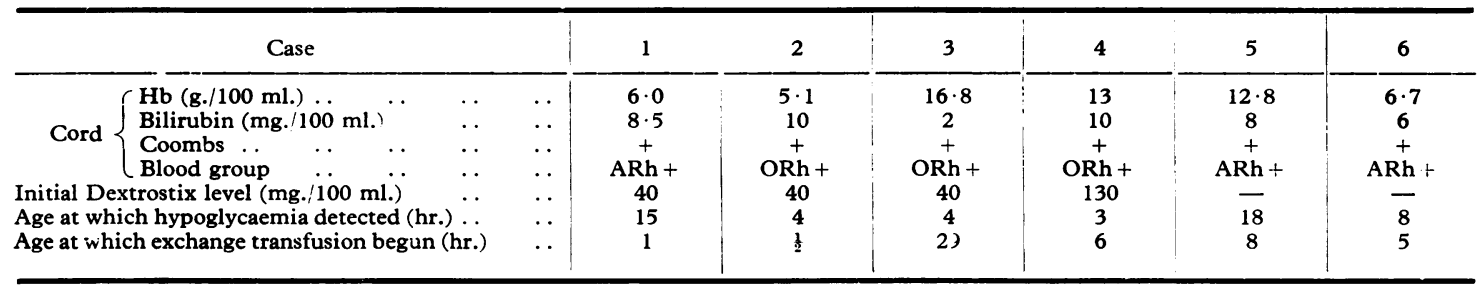

taneously from a similar episode at the start of the fourth exchange transfusion.

Intravenous fructose was discontinued 72 hours after birth when the infant was feeding well. Thereafter he developed the inspissated bile syndrome, but at the age of 1 year was developing normally.

Case 3. This small-for-dates infant developed twitching movements when aged 4 hours, at which time Dextrostix failed to record and blood glucose was under $5 \mathrm{mg} . / 100 \mathrm{ml}$. Intravenous dextrose relieved the symptoms and was continued. The serum bilirubin rose to $15 \mathrm{mg}$. $/ 100 \mathrm{ml}$. 29 hours after birth. The infant collapsed after $40 \mathrm{ml}$. of the exchange transfusion with metabolic acidosis $\left(p \mathrm{H} \mathrm{7 \cdot 14}, \mathrm{PCO}_{2}\right.$ $43 \mathrm{~mm}$. $\mathrm{Hg}$, base deficit $15 \mathrm{mEq} / \mathrm{l}$., Dextrostix $40 \mathrm{mg}$./ $100 \mathrm{ml}$.) which was corrected and the exchange completed. In the period 52 to 84 hours after birth, intravenous $20 \%$ fructose $3.5 \mathrm{ml}$. hourly was substituted for dextrose, and oral feeding started. The infant sucked poorly, and had tremulous movements. Dextrostix recorded between 40 and $0 \mathrm{mg} . / 100 \mathrm{ml}$. and true glucose was under $5 \mathrm{mg} . / 100 \mathrm{ml}$. on one test. Thereafter oral feeding maintained satisfactory blood glucose levels. Further development has been satisfactory.
Case 4. This infant with moderately severe haemolytic disease developed tremulous movements 3 hours after birth, at which time Dextrostix failed to record and true blood glucose was $7 \mathrm{mg} . / 100 \mathrm{ml}$. The symptoms were relieved by intravenous dextrose, which was continued. There was slight lethargy with occasional tremulous movements during the four exchange transfusions but his condition was otherwise satisfactory. Dextrostix persistently recorded $40 \mathrm{mg}$./ $100 \mathrm{ml}$., true glucose levels varying between 35 and $54 \mathrm{mg} . / 100 \mathrm{ml}$. When aged 5 days hypocalcaemic tetany was controlled with oral calcium chloride. Further development has been normal.

Case 5. This infant was admitted to hospital when aged 4 hours, with moderately severe erythroblastosis fetalis. She collapsed after $120 \mathrm{ml}$. blood had been exchanged $\left(p \mathrm{H} 7 \cdot 06, \mathrm{PCO}_{2} 50 \mathrm{~mm}\right.$. $\mathrm{Hg}$, base deficit $15 \mathrm{mEq} / \mathrm{l}$., Dextrostix $40 \mathrm{mg} . / 100 \mathrm{ml}$.), but improved with correction of metabolic acidosis. However, 18 hours after birth an attack of apnoea with bradycardia occurred, when Dextrostix failed to record and the blood glucose was under $5 \mathrm{mg} . / 100 \mathrm{ml}$. Intravenous dextrose produced marked improvement. Oral glucose feeds did not control symptoms and continuous intravenous dextrose was given from 30 hours. 36 hours 
after birth persistent twitching of all limbs started. Dextrostix then recorded $65 \mathrm{mg} . / 100 \mathrm{ml}$., serum calcium $6.8 \mathrm{mg} . / 100 \mathrm{ml}$., and bilirubin $3 \mathrm{mg} . / 100 \mathrm{ml}$. In spite of intravenous calcium gluconate and oral chloral hydrate the convulsions continued to death 49 hours after birth. Necropsy revealed massive bilateral parietal lobe and subdural haemorrhage. Slight hypertrophy and hyperplasia of the islets of Langerhans were noted, as well as the usual features of erythroblastosis fetalis.

Case 6. This severely affected infant was admitted to hospital 4 hours after birth, rectal temperature being only $31{ }^{\circ} \mathrm{C}$. A slow exchange transfusion of $150 \mathrm{ml}$. blood was started an hour later. At its completion the infant was lethargic, with irregular respiratory movements (Dextrostix not recording, blood glucose unaer $5 \mathrm{mg} . / 100 \mathrm{ml}$.; $\mathrm{pH} \mathrm{6.94}, \mathrm{PCO}_{2} 68 \mathrm{~mm}$. $\mathrm{Hg}$, base deficit $17 \mathrm{mEq} / \mathrm{l}$.). Intravenous dextrose produced marked improvement and the metabolic acidosis was then corrected. Blood glucose levels varied from 30 to less than $5 \mathrm{mg} . / 100 \mathrm{ml}$, and were only maintained with supplements of $50 \%$ dextrose to the continuous $10 \%$ intravenous infusion. 58 hours after birth she developed generalized convulsions with shrill cry and arching of the back; blood tests showed the following. Glucose $16 \mathrm{mg} . / 100 \mathrm{ml}$., serum bilirubin $16 \mathrm{mg} . / 100 \mathrm{ml}$. (indirect $9 \mathrm{mg}$.), haemoglobin $9 \mathrm{~g} . / 100 \mathrm{ml}$. $10 \mathrm{ml} .50 \%$ intravenous dextrose and $50 \mathrm{ml}$. blood transfusion produced no improvement. Death occurred 78 hours after birth. Necropsy revealed a large intraventricular haemorrhage but no evidence of kernikterus. The usual featurcs of severe erythroblastosis fetalis including hypertrophy and hyperplasia of the islets of I,angerhans were noted.

\section{Discussion}

The 6 cases described present a clinical pattern sufficiently similar for a brief analysis of the salient features to be made. However, 2 infants died of massive intracranial haemorrhage, one of whom also had hypothermia, both being conditions that are capable of producing neonatal hypoglycaemia. The incidence of symptomatic hypoglycaemia in the remaining 4 infants is over $4 \%$ of the 86 cases of haemolytic disease during the same period, which is in contrast to an incidence of $0.21 \%$ for all births in the Queen Mother's Hospital. This supports the contention that infants with erythroblastosis fetalis are more prone to develop hypoglycaemia.

Hypoglycaemia occurring in infants of diabetic mothers is probably related to a functional hyperinsulinism (Baird and Farquhar, 1962), whereas this is not the cause of the idiopathic symptomatic hypoglycaemia of the newborn. A comparison of the clinical course in these 6 infants with these two types might help to indicate any part played by hyperinsulinism.
Thus, in reported series of transient symptomatic hypoglycaemia of the newborn there is a male: female predominance of $2: 1$ and up to $65 \%$ of infants are dysmature. Conversely, the infants of diabetic mothers are usually at or above the weight expected for their gestational age (Cornblath and Schwartz, 1966). Of the present 6 cases, 4 were female ( 2 died) and 2 were dysmature (1 died) with a weight below the 10th centile (Lubchenco et al., 1963). Of 5 previously recorded infants, 4 were female and 2 were dysmature by weight (Hazeltine, 1967; Lucey et al., 1967). The oedema of hydrops fetalis gives falsely high body weights, and therefore the true incidence of dysmaturity may be higher. In all 6 cases the onset of hypoglycaemia was within 18 hours of birth, in 3 cases being within 4 hours of birth, but the hypoglycaemia recurred if treatment was discontinued before 3 days of age. In cases of transient symptomatic hypoglycaemia of the newborn symptoms usually begin from 12 to 72 hours after birth and treatment usually needs to be continued for up to 3 days. Infants born of diabetic mothers commonly develop hypoglycaemia within 2 to 4 hours of birth, and treatment, if required, can normally be quickly discontinued (Cornblath and Schwartz, 1966).

In significant hypoglycaemia occurring in association with haemolytic disease of the newborn, treatment is presumably required to prevent brain damage (Anderson, Milner, and Strich, 1966). Glucose is also necessary in the conjugation of bilirubin (Billing and Lathe, 1958). Thus, there is a double indication for urgent treatment of these infants. Hypoglycaemia occurring in infants born of diabetic mothers and in infants suffering from respiratory distress syndrome of the newborn can be controlled with intravenous fructose solutions (McCann et al., 1966; Hutchison et al., 1964), whereas this may not be possible in transient symptomatic hypoglycaemia of the newborn (Campbell et al., 1967). Treatment with intravenous fructose was attempted in Case 2 with only limited success, there being very low true glucose levels in spite of adequate levels of blood total reducing substances, suggesting inadequate utilization of the circulating fructose. One dysmature infant, Case 3, who had relatively mild haemolytic disease of the newborn, was also given intravenous fructose for a short period from 52 to 84 hours of age, but it seems probable that the hypoglycaemia was spontaneously resolving at that period. In view of the poor response to intravenous fructose in Cases 2 and 3, it is suggested that the routine treatment should be intravenous dextrose (Campbell 
et al., 1967). Liver glycogen stores are probably defective in severe haemolytic disease of the newborn, especially in prematures, and in many cases of transient symptomatic hypoglycaemia of the newborn (Shelley and Neligan, 1966), whereas in infants born of diabetic mothers they are usually adequate (Cornblath and Schwartz, 1966). This accords with the length of time for which treatment is required.

Hyperinsulinism as a causative factor has been suggested by the finding at necropsy of hypertrophy and hyperplasia of the islets of Langerhans in severely affected infants with haemolytic disease of the newborn (Liebegott, 1938; Brahler and Dellenbach-Hellweg, 1963). This abnormality was found at necropsy in Cases 5 and 6 . The significance of this has again been raised by the finding at necropsy of an increased extractable pancreatic insulin content (Driscoll and Steinke, 1967). This suggests that cases of erythroblastosis fetalis are at risk of developing symptomatic hypoglycaemia. However, Driscoll (1966) felt that symptomatic hypoglycaemia was not usually a component of the grave neonatal syndrome of congenital hydrops, and suggested that haemolysates acted as anti-insulin agents. Plasma insulin readings have not as yet been systematically recorded in haemolytic disease of the newborn, either in uncomplicated cases or in those complicated by symptomatic hypoglycaemia, but this omission is now being remedied. Hazeltine (1967) suggests that the hypoglycaemia results from reactive hyperinsulinism to the glucose load of the exchange transfusion blood. However, in these 6 infants the onset of hypoglycaemia preceded the first exchange transfusion in 2 infants, and started afterwards in 4 infants. Hypoglycaemia occurring during exchange transfusion would be unusual (Anderson et al., 1963). The part, if any, played by hyperinsulinism in causing symptoms in these infants remains uncertain. Apart from the early onset of symptoms, the clinical pattern was more in keeping with that seen in the transient symptomatic hypoglycaemia of the newborn than in the infants born of diabetic mothers.

It is suggested that cases of erythroblastosis fetalis are at risk in respect to hypoglycaemia. To detect the infants requiring treatment, Dextrostix testing every 4 or 6 hours for the first day of life seems indicated. This is particularly important in very severely affected infants and in those who have any unexplained symptom.

\section{Summary}

Six cases of hypoglycaemia associated with haemolytic disease of the newborn are described. There is an increased risk of hypoglycaemia in infants with haemolytic disease of the newborn, particularly in those who are severely affected. Frequent Dextrostix testing in the first day of life is recommended in these infants. In 2 infants who died from intracranial haemorrhage, hypertrophy with hyperplasia of the islets of Langerhans was noted at necropsy. The 4 surviving infants are developing normally.

It is a pleasure to record my thanks to Professor J. H. Hutchison and Dr. Margaret M. Kerr for advice and encouragement during the preparation of this paper.

\section{REFERENCES}

Anderson, J., Marks, V., Tomlinson, R. W. S., and Walker, w' (1963). Changes in the blood concentration of glucose, $\alpha$-oxoglutarate, pyruvate and citrate during exchange transfusion in haemolytic disease of the newborn. Arch. Dis. Childh., 33, 481.

Anderson, J. M., Milner, R. D. G., and Strich, S. J. (1966). Pathological changes in the nervous system in severe neonatal hypoglycaemia. Lancet, 2, 372.

Baird, J. D., and Farquhar, J. W. (1962). Insulin-secreting capacity in newborn infants of normal and diabetic women. ibid, 1,71 .

Billing, B. H., and Lathe, G. H. (1958). Bilirubin metabolism in jaundice. Amer. F. Med., 24, 111.

Brahler, H. J., and Dellenbach-Hellweg, G. (1963). Die Langerhansschen Inseln bei fetaler Erythroblastose. Virchows Arch. path. Anat., 336, 544.

Campbell, M. A., Ferguson, I. C., Hutchison, J. H., and Kerr, M. M. (1967). Diagnosis and treatment of hypoglycaemia in the newborn. Arch. Dis. Childh., 42, 353.

Cornblath, M., and Schwartz, R. (1966). Disorders of Carbohydrate Metabolism in Infancy, chap. 4 and 5, pp. 57 and 82. W. B. Saunders, Philadelphia and London.

Driscoll, S. G. (1966). Hydrops fetalis. New Engl. F. Med., 275, 1432.

- -, and Steinke, J. (1967). Pancreatic insulin content in severe erythroblastosis fetalis. Pediatrics, 39, 448.

Gerrard, J. (1952). Kernicterus. Brain, 75, 526

Hazeltine, F. G. (1967). Hypoglycemia and Rh erythroblastosis fetalis. Pediatrics, 39, 696.

Hutchison, J. H., Kerr, M. M., Douglas, T. A., Inall, J. A., and Crosbie, J. C. (1964). A therapeutic approach in 100 cases of the respiratory distress syndrome of the newborn infant. ibid., 33, 956.

Liebegott, G. (1938). Zur Pathogenese des Hydrops congenitus. Beitr. path. Anat., 101, 319.

Lubchenco, L. O., Hansman, C., Dressler, M., and Boyd, E. (1963). Intrauterine growth as estimated from liveborn birth-weight data at 24 to 42 weeks of gestation. Pediatrics, 32, 793.

Lucey, J. F., Randall, J. L., and Murray, J. J. (1967). Is hypoglycemia an important complication in erythroblastosis fetalis. Amer. F. Dis. Child., 114, 88.

McCann, M. L., Adam, P. A. J., Likly, B. F., and Schwartz, R. (1966). Prevention of hypoglucosemia by fructose in infants of diabetic mothers. New Engl. 7. Med., 275, 8.

MacRae, D. J., and Palavradji, D. (1965). Acid-base balance in exchange transfusion. $\mathcal{F}$. Obstet. Gynaec. Brit. Cwlth, 72,

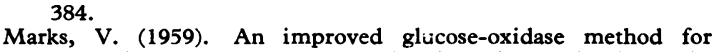
determining blood, C.S.F. and urine glucose levels. Clin. chim. Acta, 4, 395.

Shelley, H. J., and Neligan, G. A. (1966). Neonatal hypoglycaemia. Brit. med. Bull., 22, 34.

Correspondence to Dr. H. V. Price, Department of Child Health, University of Dundee, 11 Dudhope Terrace, Dundee. 